\title{
Public Projects for Digital Inclusion of Micro and Small Enterprises in Brazil
}

\author{
Aline Cristina Helfenstein ${ }^{1}$, Debora Fernandes de Souza Mendes ${ }^{1}$, Douglas Fernando Batista Neis ${ }^{1}$, Elielza Camargo \\ Souza $^{1}$, Rafael Vicente Martins dos Reis ${ }^{1} \&$ Flavio de Sao Pedro Filho ${ }^{1}$ \\ ${ }^{1}$ Public Administration (PROFIAP), Rondônia Federal University, Rondônia, Brazil \\ Correspondence: Douglas Fernando Batista Neis, Professional Master's Program in Public Administration \\ (PROFIAP), Rondônia Federal University, Rondônia, Brazil.
}

Received: August 13, 2020

Accepted: September 26, $2020 \quad$ Online Published: October 8, 2020

doi:10.5430/ijba.v11n6p9

URL: https://doi.org/10.5430/ijba.v11n6p9

\begin{abstract}
The research axis revolves around how public projects can influence the digital inclusion of micro and small enterprises. The objective proposed in the work is to study the concepts of information technology for public projects aimed at the digital inclusion of MSEs. The methodology used has a qualitative approach of a descriptive nature, based on content analysis. Through the study it was concluded that the use of technologies contributes to the growth and maintenance of micro and small enterprises in the competitive market, but that the resources to accompany the technological evolution are scarce, and therefore, the development of public projects aimed at inclusion of micro and small businesses seems to be essential.
\end{abstract}

Keywords: public projects, micro and small enterprises, digital inclusion, competitive market

\section{Introduction}

Information technology (IT), in recent years, has dominated the market, whether in the public sector, industries or companies. Business enterprises that have not updated themselves to new technological models, have been losing competitive advantage and, consequently, are doomed to economic failure. For larger companies, this advance is easier, as they have better access to financial resources, as well as access to acquisition options. However, smaller business, such as micro and small enterprises, known as MSEs, have a revenue that does not allow them to keep up with the necessary advances to remain in the competitive market, but with the support of public projects, it's possible for them to achieve optimal results.

Given the reality presented, this study aims to broaden the horizon of how public projects can be implemented for the development of digital inclusion at the MSEs. To meet this theoretical gap, the general objective of this work is to study the concepts of the IT for public projects focusing at the digital inclusion of MSEs. In order to achieve the intended results, the study is going to present the concepts of information technology for digital inclusion in MSEs, characterize Knowledge Management in MSEs supported by Bloom's Taxonomy and build a cognitive scenario capable of generating practical engagement with the concepts considered in the study. The question to be answered by the research is: What concepts related to information technology can be used in public digital inclusion projects for MSEs?

The article is structured into five topics, starting with the present, introductory, followed by the literature review, where the concepts related to the subject were gathered, and by the methodology, where the tools and methods used for the development of the work were pointed. The results will be treated in accordance with the proposed objectives and the conclusion seeks to record the answer to the research question. Finally, there are the reference indications that served as a source in the preparation of this task.

\section{Literature Review}

According to Soares and Beirão Junior (2011), public projects goals are to create new products or services, adding changes and innovations in the production processes or services provisions. Siqueira (1985) defines a project as a grouping of interdependent actions that are carried out for a specific purpose, with a predetermined duration in favor of the execution of something. With this in mind, it becomes clear how important the development of public projects 
is to allow that technological innovations occur in MSE since it appears that a public project has adequate characteristics to promote necessary changes in these business.

The changes in organizations, mainly technological, have been taking place for some time. The main changes started to happen with the industrial revolution, where the production and management models were drastically changed, increasing the challenge of managing these new organizations, as indicated Soares and Beirão Junior (2011).

\subsection{Concepts of Information Technology, Digital Inclusion and Micro and Small Enterprises}

The next sub-chapters intended to introduce the theoretical survey of concepts related to information technology, digital inclusion and micro and small enterprises.

\subsubsection{Information Technology Concepts}

Information Technology (IT) or Information and Communications Technology (ICT) has been gaining space as an essential part of organizations management resources and the largest business enterprises has been using IT intensively. This data is also incorporated to MSEs, as pointed out by Silva and Teixeira (2014). Lunardi, Dolci and Maçada (2010) registered that each new year, the number of organizations that use IT in their operations grows.

According to Laurindo et al. (2001) information technology is a specific area that brings together media such as software, hardware and people-wares, in order to offer data, information and knowledge to users. In addition, Maciel and Fernandes (2011) define technology as a grouping of knowledge, information and means used in an organized way to carry out some activity.

\subsubsection{Digital Inclusion Concepts}

Cerquinho et al. (2015) shows that digital inclusion needs to be seen as a political action and must be seriously treated by the government through actions and instruments that result in the expansion of individuals' basic capital. In collaboration with this concept, Cabral Filho and Cabral (2010) state that digital inclusion is part of a politic issue, which depends on the formulation, visibility and sustainability of public policies to be undertaken by the government. Complementing the concept, Cardoso and Pedro Filho (2019), when studying the role of technological innovation in the public sector, argue that institutions need innovation, qualifying their processes in order to optimize the results demanded. Thus, it is observed that digital inclusion or technological innovation is a major factor to be considered in all types of organizations, given the changes that have been occurring in society and in the competitive market.

As explained by Cordeiro Neto and Feitosa (2010), digital inclusion is the combination of activities of interest to the community through an interactive platform with public or private organizations, using information and communications technology. In collaboration with the concept, Miranda et al. (2017) defines that digital inclusion is to socialize access to information technologies, allowing all people to use the available technological resources and platforms. Ferreira et al. (2020) study states that the reality of business today is highly competitive, due to the rapid changes that occur due to the evolution of technology and digital media. In this sense, the digital inclusion of enterprises is about promoting the use of various technological resources by different types of companies, even the smallest ones, in order to promote their survival amid competitiveness.

\subsubsection{Micro and Small Enterprises Concepts and Definition}

For tax and legal purposes, considering the most recent changes promoted by Complementary Law No. 155/2016, micro-enterprise is a simple for-profit company or an entrepreneur referred in art. 966 of the Brazilian Civil Code, duly registered, which maximum annual revenue of $\mathrm{R} \$ 360,000.00$ (three hundred and sixty thousand reais); on the other hand, small enterprise is the one that, under the same conditions above, have annual revenue between $\mathrm{R} \$ 360,000.00$ (three hundred and sixty thousand reais) and $\mathrm{R} \$ 4,800,000.00$ (four million and eight hundred thousand reais) (BRAZIL, 2016).

Barreto et al. (2014) explains that micro and small enterprises are responsible for about $60 \%$ of the jobs generated in Brazil. In other words, they are key organizations for the country's development. Similarly, Bischoff and Wood (2013) found in their studies that MSEs are responsible for 55\% of the jobs in South Africa and for 22\% of it's GDP (a country marked by high unemployment), making this segment responsible for providing jobs and an real alternative for citizens who have failed to benefit from apartheid to leave poverty. Corroborating this position, Lunardi, Dolci and Maçada (2010) affirm that MSEs have been fundamental in the development and maintenance of the country's economy. It is observed that both in Brazil, as in other countries, stimulating the development of MSEs is important, since the success of this category must reflect in a more balanced economic scenario. 


\subsection{Knowledge Management in MSEs Supported by Bloom's Taxonomy}

In this topic theories related to knowledge management and Bloom's Taxonomy will be presented and the concepts and applications of those to the MSEs.

\subsubsection{Knowledge Management Concepts}

Yafushi, Almeida and Vitoriano (2019) define knowledge as a continuation of the human being's mind, that has extracts of ideas, values and beliefs and experiences lived throughout a life, capable of modifying the environment in which it lives, generating new knowledge and understanding. For Gonzales and Martins (2017), organizational knowledge should be considered currently as an asset, which, although intangible, is capable of producing a competitive advantage for the organization that uses it. In the same way, Severo et al. (2019) states that knowledge management has been occupying an important space in the function of defining strategies for performance in organizations.

Correa, Ziviani and Chinelato (2016) show that Knowledge Management has as its main objective the promotion of the performance of organizations through knowledge. Yafushi, Almeida and Vitoriano (2019) bring that knowledge is divided between tacit (which derives from everyday experiences) and explicit (which is obtained by formal means, the knowledge taught). For Gonzales and Martins (2017), knowledge is an intangible nature and occurs in an evolutionary way, through the organization of data and learning.

Severo et al. (2019) states that good practices in knowledge management provide competitive advantage for companies that are able to apply it, and, consequently, brings to the organizations the success. In this same scenario Yafushi, Almeida and Vitoriano (2019) affirm that organizations need to have an adequate posture and make efforts to use the necessary tools to promote continuous learning of their collaborators, in order to achieve success in the application of Knowledge.

\subsubsection{Bloom Taxonomy Concepts}

Bloom's taxonomy is understood by Defaveri, Baldissera e Silva (2019) as a way to hierarchically organize the learning process, assisting the planning, organization and control of learning. Defaveri, Baldissera and Silva (2019) present that Bloom divided taxonomy into three dimensions of knowledge: cognitive (memory and development of intellectual skills), affective (interests, attitudes and values) and psychomotor (ability with objects or tools).

According to Defaveri, Baldissera e Silva (2019) taxonomy facilitated the use of learning instruments in a more structured way, including technological advances, in order to promote the teaching and learning process; this so called hierarchical way of occurring, means that in order to obtain deeper knowledge, the individual first needs the shallower knowledge. Ferraz and Belhot (2010) state that cognitive thinking must be structured, so that it can also be passed on as acquired knowledge. In this sense, Bloom's taxonomy is a way of structuring knowledge, obtaining it in a primary way and moving towards more complex forms, so that this knowledge remains and is remembered in the future.

\subsection{Public Project Concepts Valid for Digital Inclusion and Support to MSEs}

For Vargas (2016), a project is a set of actions organized with determined time and costs, performed by people or organizations, using the necessary resources and inputs, aimed at achieving a certain objective. Coelho et al. (2014) define as project management in public administration, the management and application of knowledge, skills and actions that seek to execute objectives in a determined time and with a determined budget, requiring different knowledge, mainly about the current legislation. According to Vargas (2016), projects can be short or long, can involve few or many people and they can reach not only the organization, but also external actors, such as suppliers and customers.

According to Lunardi, Dolci and Maçada (2010), organizations have been pressured by technological innovation and competition in investing in IT. For Chapuis (2019) the main reason for the discrepancy in the economic distribution is the inequalities practiced in the market. Santos (2019) states that in the midst of an increasingly competitive market, companies must develop differential skills to be successful. Lunardi, Dolci and Maçada (2010) adds that as technologies reach more accessible values, smaller businesses can also enjoy the benefits allow by them. For Ferreira et al. (2020) companies, concerned with staying in business, have been constantly looking for alternatives to keep up with changes and innovate in their products and services, in addition to using technology to reduce operating costs.

In this sense, the development of public projects seems essential for the promotion of valid structuring means in the technological development of micro and small enterprises. As an example, Cunha and Bourlegat (2016), in their studies, observed that Complementary Law 123/2006 has brought advances for the participation of MSEs in bidding, 
and consequently, a strengthening for this category of companies. It is clear that this law is a public project that has become an excellent public policy and that it has produced excellent results in the inclusion of MSEs in the competitive bidding market.

\section{Methodology}

The present study is a qualitative research, with a descriptive design, as defined by Creswell (2010). The methodology to be used is the one proposed by Bardin (1977) - content analysis - and is based on the selected theories.

The content analysis methodology, according to Bardin (1977), is a methodological research tool for working with words and their meanings, seeking to find information that is not properly expressed in the words, determining psychological, sociological, historical variables, etc. Schiavini and Garrido (2018) in their studies, reinforce Bardin's definition when they define the technique as a method where analysis of communications is carried out in order to understand the message beyond what is explicit. Flick (2013) states that it is a classic way of analyzing texts from different sources. Gonçalves (2016) conceptualizes such an approach as a social science technique whose objective is to investigate phenomena through message research and analysis. For Schiavini and Garrido (2018) this technique is intended for qualitative studies and has achieved greater credibility every day, being applied in several areas in which social sciences stand out.

Flick (2013) also defines that the method is based on the use of categories, which are extracted from the theory. Therefore, the present study was based on the search for e-books and scientific articles on the digital platforms Spell and Periódicos Capes, searching for the keywords related to the research objectives, as detailed in figure 1, 40 studies were selected for reading, 14 being eliminated and 26 were used in the analysis of the present study.

According to the theories obtained by the searching for keywords, the Scientific Theoretical Review was built, which will serve as a support for defining the categories to be explained, according to Flick (2013), in chapter 4.

\section{Analysis of Content and Discussion}

The content obtained through the theoretical scientific review was analyzed using the content analysis technique, already mentioned in the chapter on methodological procedures. Based on this, the chapter was subdivided according to the studied themes, analyzing the concepts and applications with a view to promoting the digital inclusion of MSEs through public projects.

\subsection{Information Technology, Digital Inclusion and Micro and Small Enterprises}

This subchapter will present the results founded and their analysis in relation to the theories involving information technology, digital inclusion and micro and small enterprises regarding their application in MSEs.

\subsubsection{Information Technology}

Through the theories detected about information technology, the Table 1 was elaborated, compiling the essential elements related to the subject and their respective descriptions.

Table 1. Descriptive elements related to information technology

Elements Descriptive

1.1 Information technology is necessary for the production and supply of higher quality products and services, in addition to

1. Information Technology

Silva and Teixeira (2014).

Lunardi, Dolci and Maçada (2010).

Laurindo et al. (2001).

Maciel and Fernandes (2011).

2. Organizational Management Resources

Silva and Teixeira (2014). allowing greater participation in the competitive market.

1.2 Use of digital platforms available in public agencies that contain information technology inherent to MSEs to reduce costs with hiring.

1.3 Search for tools, where MSEs can understand the usual facilitators with the greatest advantage and cost-benefit possible, such as relationships, management, control and speed of results.

2.1 Management resources in organizations are related to capital and materials that assist in the management of the organization.

2.2 These resources can be software, hardware or even digital 
platforms that can improve management.

3.1 The constant changes in the business world requires from

3. Update dynamics organizations a constant updating.

Lunardi, Dolci and Maçada (2010).

3.2 The updates are related to technological, tax, legal changes and mainly to the needs and wishes of customers.

\section{Plataforms}

Lunardi, Dolci and Maçada (2010).

\section{Operations}

Lunardi, Dolci and Maçada (2010).

6. Software, hardware and peoplewares

Laurindo et al. (2001)
4.1 Means developed through technology to integrate people and information.

5.1 Operations are the transactions of organizations that, when executed by technology, esures a gain of agility, quality and efficiency.

6.1 Softwares are the programs, platforms or applications used by organizations and people in order to carry out certain activities.

6.2 Hardwares are technology equipments as computers, reading equipments, encoders, production machines, smartphones, etc.

6.3 The peoplewares are the people involved on the process of information, production and decision.

6.4 Technology requires peoplewares, as they have accumulated knowledge about the actions that IT has contributed to improve.

7. Grouping of knowledge, information and means

7.1 It is the set of instruments, whether intellectual or material, to be used for the development of the business enterprise, its products and / or services.

Maciel and Fernandes (2011).

Source: Elaborated by the authors

Information technology is responsible for providing means that facilitate the management of organizations, increase the quality, speed and excellence of products and services delivered by companies. Micro and small enterprises need to have access to these technological innovations, in order to remain competitive in the current market scenario that is constantly changing.

\subsubsection{Digital Inclusion}

The main elements found in the theory of digital inclusion are listed in Table 2 associated with the pertinent observations related to the digital inclusion of Micro and Small Enterprises.

Table 2. Descriptive elements related to digital inclusion

\begin{tabular}{l} 
Elements \\
\hline 1. Digital inclusion \\
Cerquinho et al. (2015). \\
Cordeiro Neto and Feitosa (2010).
\end{tabular}

2. Political action

Cerquinho et al. (2015).

3. Expansion of the individual human basic capital

Cerquinho et al. (2015).

\section{Descriptive}

1.1 It is necessary to guarantee the development of all.

1.2 Actions must be implemented so that those without knowledge or access to technology can be included.

2.1 Activity that generates behavioral or organizational changes that are promoted by the state and by public agents.

2.2 It represents one of the ways to promote the digital inclusion of people or organizations.

3.1 The basic capital of individuals is their knowledge, skills and abilities for something.

3.2 Developing personal knowledge in the technology area is as important as making available means of acquiring technology.

3.3 Individuals lacking of the minimal IT skills will have great 
difficulty in the competitive market.

4.1 May be actions of change proposed by the government, to implement digital inclusion for those who are not yet involved in cyberworld.

4. Public policy

Cabral Filho and Cabral (2010).
4.2 In all aspects, they are created to promote improvement in the life of society and to fill an existing social gap.

4.3 Government must act to include companies and people in the new innovation scenario, which has been transforming the world, organizations and the economy.

5.1 Through technology it is possible to optimize results, since it reduces the time of production, improves quality and decreases costs of operations, such as staff and logistics.

5. Optimize the results

Cardoso and Pedro Filho (2019).

5.2 In addition to the production environment, the technology improves the decision-making power and management capacity of organizations, as it allows greater control over costs, expenses, profits and market prospects.

6.1 Socialization of access to ITs occurs when different social groups and organizations, large and small, have the same access to these technologies.

6.2 As prices for IT goods, inputs and services decrease, they become more accessible to the poorest people and to smaller organizations, such as MSEs.

7.1 Technological evolution is constant as the demands for them to keep getting bigger and bigger. The processes are improved every day and what was valid yesterday, today may shows as

7. Evolution of technology and digital media insufficient.

Ferreira et al. (2020).
7.2 Companies without access to the digital platforms used by the government became dependent of other organizations, like offices specialized in bidding, or companies responsible for part of their production.

Source: Elaborated by the authors

Digital inclusion is a way for make possible that people and companies have the same conditions of competition in the market and in society. Political actions must be thought of in order to promote such a process. Technological evolution will be increasingly present in all media and thus the need for updating will be consequent.

\subsubsection{Micro and Small Enterprises}

Micro and small enterprises are those organizations that have a lower annual revenue capacity. The conceptual elements related to this type of organization are shown in Table 3.

Table 3. Descriptive elements related to digital inclusion

\begin{tabular}{ll}
\hline Elements & Descriptive \\
\hline $\begin{array}{l}\text { 1. Microentreprises } \\
\text { (Brazil, 2006). }\end{array}$ & $\begin{array}{l}\text { 1.1 They are individual or simple company organizations with revenues of up to } \\
\mathrm{R} \$ 360,000.00 \text { per year. }\end{array}$ \\
\hline $\begin{array}{l}\text { 2. Small enterprises } \\
\text { (Brazil, 2006). }\end{array}$ & $\begin{array}{l}\text { 2.1 Small enterprises are slightly larger organizations than the micro-sized having } \\
\text { a maximum annual revenue of } \mathrm{R} \$ 4,800,000.00 .\end{array}$ \\
\hline 3. Country development & $\begin{array}{l}\text { 3.1 Micro and small enterprises are responsible for the majority of jobs generated } \\
\text { in Brazil. }\end{array}$ \\
\hline
\end{tabular}


(Barreto et al., 2014)

3.2 The economic and technological development of MSEs will result in a country that is also more developed.

3.3 MSEs, although smaller, are extremely relevant to the country, moving a large part of the market. They are the majority in number of organizations, and, therefore, show themselves very important.to the economy.

4.1 A country's economy depends on its ability to generate jobs, since through them citizens acquire their purchasing power and livelihood - their wages or

4. Maintaining the economy

4.2 Because they are the majority in Brazil, MSEs are agents of maintenance of the economy, if they cannot keep up with the competitive market, they will soon have several unemployed people and the economy in crisis.

Source: Elaborated by the authors

MSEs are actors that generate most of the jobs existing in Brazil, thus responsible for a good part of the country's development and maintenance of the economy. It is through these companies that the majority of the population participates in the economic flow, it is the small grains participating together in the movement of a country, which, if it were not so, would be dominated by large companies.

\subsection{Knowledge Management in MSEs Supported by Bloom's Taxonomy}

In the next sub-chapters, the results obtained in relation to the theories related to knowledge, knowledge management in MSEs and a Bloom taxonomy will be presented, as well as the relationship between those concepts with MSEs.

\subsubsection{Knowledge Management in MSEs}

Knowledge management is necessary under any circumstances. In MSEs even more, since their material, personal and financial resources are sometimes scarce and need to be supplied by outstanding skills. Table 4 below shows the main concepts related to this need.

Table 4. Descriptive elements related to knowledge management in MSEs

Elements Descriptive

Knowledge

Yafushi, Almeida and Vitoriano (2019).

Extracts of ideas, lived experiences,
tacit knowledge

Yafushi, Almeida and Vitoriano (2019).

Explicit knowledge

Yafushi, Almeida and Vitoriano (2019).

Modify the medium

Yafushi, Almeida and Vitoriano (2019).
Nowadays, knowledge and information are responsible for the differential of people and organizations. Strength has little value, but knowledge is celebrated and disputed.

Knowledge is not only based on the information learned, but also on the ideas and experiences lived by people.

Tacit knowledge, because it derives from previous experiences, must be considered, since it prevents the organization or the person from making mistakes that have already occurred.

The experience sometimes becomes a differential in the competitive market, especially in small companies, which need to stand out in some areas to meet needs in others.

This type of knowledge can be promoted, since it is composed of what is learned.

It is up to people and organizations to promote this type of knowledge, as it becomes a potential competitive factor, in addition to promoting improvement in the organization's management, production and service processes.

The accumulated knowledge of people is capable of promoting changes in the environment in which they live or operate.

Changes will always be necessary, the world is constantly changing, experiences must be used to modify behaviors, actions, paradigms and 
thus optimize results.

Organizational knowledge

Gonzales and Martins (2017).

Outline strategies for performance

Severo et al. (2019).

Correa, Ziviani and Chinelato (2016).

Gonzales and Martins (2017).
An organization's knowledge is made up of all the accumulation of tacit and explicit knowledge of its actors.

Organizational knowledge, in terms of the market, can represent a competitive differential, for example an experienced team with recent training, can produce better products, or provide excellent services.

Organizations have constantly sought to establish goals to leverage results and the correct management of existing knowledge in the organization will help in better performance; an example is the allocation of people with knowledge directed to matters of finance in the financial of the organization, promoting better use of that knowledge.

Knowledge has intangibility as nature, something that cannot be touched or felt physically, however, it is a good that should be valued in organizations.

Evolution makes the demands increase, the information changes and makes the knowledge to be evolutionary and continuous to be real.

Non-updated knowledge is not necessary in organizations, it is necessary to evolve along with changes in the world, in parallel with technologies and advances.

Promoting continuous learning, taking advantage of personal resources

Good practices in knowledge management and knowledge already existing in the appropriate positions and sectors. Promoting continuous learning, are elements present in good practices in knowledge management.

Severo et al. (2019).

The better the knowledge management, the better the result of the organization.

Source: Elaborated by the authors

\subsubsection{Bloom's Taxonomy}

Bloom's taxonomy is a proposal for organization and knowledge management. It is a tool widely used to organize knowledge and the way it is passed on to people. Table 5 shows the essential elements of this definition and how it is or can be used in the management of MSEs.

Table 5. Descriptive elements related to Bloom's taxonomy

\section{Elements Descriptive}

The hierarchical learning process is the way that Bloom's taxonomy defines

Learning process as adequate to plan, organize and control learning.

Defaveri, Baldissera e Silva (2019). This process, when promoted in organizations, provides improvement at all levels.

Learning tools Learning tools are the essential means for promoting improved knowledge.

Defaveri, Baldissera e Silva (2019).

Technology has been an increasingly used instrument, as it manages to reach distant and updated knowledge.

Structuring cognitive knowledge is making it capable of reproduction as

Cognitive thinking

Ferraz and Belhot (2010) knowledge acquired from other people.

Experience-based knowledge has its role in Bloom's structure, usually associated with the most primary form of knowledge, but which is necessary to achieve deeper knowledge.

Source: Elaborated by the authors 


\subsection{Public Projects Valid for Digital Inclusion and Support to MSEs}

The use of public projects is necessary whenever there is a public order problem to be solved. Essential elements related to the theme are shown in Table 6.

Table 6. Descriptive elements related to public projects valid for digital inclusion and support to MSEs

\begin{tabular}{ll}
\hline Elements & Descriptive \\
\hline & $\begin{array}{l}\text { A project is the organized way of allocating actions that have the objective of } \\
\text { carrying out a certain activity, considering the time, inputs, human resources } \\
\text { necessary to fulfill the objective. }\end{array}$ \\
Project & $\begin{array}{l}\text { A project will depend on personal efforts in its elaboration, so that it contains } \\
\text { adequate information detailing what is intended to be solved with its execution, } \\
\text { what resources (personal and financial) will be used and what is its source, as } \\
\text { well as what will be the phases, deadlines and methodology execution. }\end{array}$
\end{tabular}

For the execution of public projects, it is necessary to manage and apply knowledge and skills.

Knowledge management and Through applied knowledge and skills, public projects are able to achieve their application objectives, and resolve a certain demand from society.

Coelho et al. (2014).

Managing knowledge is the way to promote the social good, to know the reality, the adversities and weaknesses are essential to modify it.

Investments are always complicated, as they involve spending resources,

Invest in IT

Lunardi (2010).

Ferreira et al. (2020).

Chapuis (2019). especially for small and microenterprises. MSEs have a great need for technology to follow the market, but few resources for such provision.

The technology has been responsible for leveraging sales, improving products and services and thus, becoming a competitive differential for the organizations that have it.

In a social scenario, in which people and organizations are in different positions when it comes to resources, government support is needed so that the less fortunate can keep up with technologies and thus remain equal to their competitors.

Public projects that pursue the technological inclusion of MSEs are an efficient choose to reduce the technological discrepancy that exists between large and small companies, allowing them to compete with more fair conditions with those.

Source: Elaborated by the authors

\section{Conclusions}

Well-managed knowledge is the main ally of organizations for success in carrying out their activities. Bloom's taxonomy suggests a hierarchy of the knowledge construction process, where initially, it is necessary to delimit tactical and superficial knowledge, and then, through learning processes, this knowledge can be improved reaching deeper levels.

It is observed in Brazil that micro and small enterprises do not have sufficient means to improve their knowledge and access to it. Technology has proven to be a great ally for the development of organizations, but MSEs have scarcest resources and sometimes are unable to keep up with the due technological evolution.

It shows that the development of public projects aimed at the digital inclusion and technological innovation of MSEs is valid due to the inequality scenario faced by these companies. They may not have the same credit capacity as large companies, but, together, they turn the economy around, generate most of the jobs in the country and, for this reason, they need government assistance to remain in competition. 
It was observed in this study, that some essential items may be part of the execution of a public project for the technological inclusion of the MSEs, such as the provision of public platforms with the necessary technology to assist MSEs in the management of their resources, sales or provision of services, as well as improving the efficiency of its activities and also the training of entrepreneurs and employees, producing knowledge and skills in new technologies for this group.

Promoting the purchase of equipment or hiring technology services with differentiated taxation, provision of public platforms, promoting training related to technology for MSEs entrepreneurs and their employees, are examples of actions that can be implemented by means of public digital inclusion projects for MSEs.

Regarding the question of this research, it is observed that all the concepts related to information technology listed in this work can be used in public digital inclusion projects for MSEs, since information technology is present in all areas and must be introduced more effectively in smaller companies, in order to promote greater inclusion of these and consequently more equal participation power in the competitive market.

As being a theoretical-conceptual review, the work presents as a limitation the absence of an empirical approach. Therefore, for future research it is suggested to carry out an empirical research where micro and small enterprises are probed about the knowledge about information technology, digital inclusion and knowledge management, in order to determine the degree of information of this segment regarding to the theme.

\section{References}

Bardin, L. (1977). Content Analysis. Lisbon: Edições 70.

Barreto, L. K. S., Montenegro, C. B., Souza, K. B. M., Rocha Neto, M. P., \& Souza, P. V. D. (2014). Licitação como uma ferramenta estratégica de crescimento e manutenção para as microempresas e empresas de pequeno porte. Revista Global Manager, 14(1), 1-18. Retrieved from http://ojs.fsg.br/index.php/global/article/view/1101

Bischoff, C., \& Wood, G. (2013). Micro and small enterprises and employment creation: A case study of manufacturing micro and small enterprises in South Africa. Development Southern Africa, 30(4/5), 564-579. https://doi.org/10.1080/0376835X.2013.817303

Cabral Filho, A. V., \& Cabral, E. D. T. (2010). Inclusão digital para a inclusão social: perspectivas e paradoxos. Revista Debates, 4(1), 11-28. https://doi.org/10.22456/1982-5269.12520

Cardoso, G. B., \& Pedro Filho, F. S. (2019). Inovação em tecnologia da informação com base no Business Process Management (BPM). Revista Interdisciplinar Científica Aplicada, Blumenau, 13(4), 70-92. Retrieved from https://rica.unibes.com.br/rica/article/view/1046/784

Cerquinho, K. G., Tavares, W., Paula, A. P. P., \& Vitorino, I. A. (2015). Inclusão Digital para quê e para quem? Observação do Portal Inclusão Digital do Governo Federal Brasileiro. Cadernos Gestão Pública e Cidadania, 20(67), 172-193. https://doi.org/10.12660/cgpc.v20n67.32927

Chapuis, G. A. L. (2019). Compras públicas e desenvolvimento local: um estudo no instituto federal de educação, ciência e tecnologia de Rondônia. Master's thesis, Federal University of Rondônia Foundation, Porto Velho, Rondônia, Brazil. Retrieved from https://drive.google.com/file/d/0By4OKVm-raVEZ0psczVpSURyZ0t0WHF0dXYwbENmRU9UYUZB/view

Coelho, R. M., Souza, R. R., Silva, G. G. R., \& Ferrão, C. (2014). Gestão de Projetos no setor público: legislações orçamentárias. In Conference Proceedings of the III International Symposium on Project Management (III SINGEP) and II International Symposium on Innovation and Sustainability (II S2IS). São Paulo, SP, Brazil. Retrieved from https://singep.org.br/4singep/resultado/344.pdf

Complementary Law ${ }^{\circ}$. 123. (2006). Institutes the National Statute of Micro and Small Enterprises. Brasília, DF. Brazil. Retrieved September 28, 2019, from http://www.planalto.gov.br/ccivil_03/Leis/lcp/lcp123.htm

Cordeiro Neto, J. R., \& Feitosa, A. L. C. (2010). Ações de inclusão digital em Nova Olinda-CE: articulação de experiências pró-desenvolvimento local?. APGS, 2(3), 22-44. Retrieved from https://periodicos.ufv.br/apgs/article/view/4026

Correa, F., Ziviani, F., \& Chinelato, F. B. (2016). Gestão do conhecimento: uma analise metabibliométrica. Perspectivas em Gestão \& Conhecimento, 6(2), 208-224. Retrieved from https://periodicos.ufpb.br/ojs2/index.php/pgc/article/view/48474

Creswll, J. W. (2010). Research design: qualitative, quantitative and mixed methods approaches (3rd ed.). Porto Alegre: Artmed. 
Cunha, M. A. D. A. S., \& Bourlegat, C. A. L. E. (2016). Inclusão e perspectivas de desenvolvimento da microempresa e empresa de pequeno porte no processo de compras governamentais na esfera federal. Interações, 17(3), 410-421. https://doi.org/10.20435/1984-042X-2016-v.17-n.3(05)

Defaveri, I. R., Baldissera, J. F., \& Silva, S. C. (2019). Taxonomia de Bloom: uma análise bibliométrica e sociométrica de periódicos internacionais. Sociedade, Contabilidade e Gestão, 14(2). https://doi.org/10.21446/scg_ufrj.v0i0.15916

Ferraz, A. P. C. M., \& Belhot, R. V. (2010). Taxonomia de Bloom: revisão teórica e apresentação das adequações do instrumento para definição de objetivos instrucionais. Gestão e Produção, 17(2), 421-431. https://doi.org/10.1590/S0104-530X2010000200015

Ferreira, J. R. S., Lima, P. R. S., Rita, L. P. S., Bittencourt, I. M., \& Souza, E. D. (2020). Apropriação e gestão da informação como estratégias de inovação: análise a partir de perfis de empresa startups. $P 2 P$ \& Inovação, $6(2)$, 59-78. https://doi.org/10.21721/p2p.2020v6n2.p59-78

Flick, U. (2013). Introducing Research Methodology: A Beginner's Guide to Doing a Research. Porto Alegre: Penso.

Gonçalves, A. T. P. (2016). Análise de Conteúdo, Análise do Discurso e Análise de Conversação: Estudo Preliminar sobre Diferenças Conceituais e Teórico-Metodológicas. Administração: Ensino e Pesquisa, 17(2), 275-300. https://doi.org/10.13058/raep.2016.v17n2.323

Gonzales, R. V. D., \& Martins, M. F. (2017). O processo de gestão do conhecimento: uma pesquisa teórico-conceitual. Gestão e Produção, 24(2), 248-265. http://dx.doi.org/10.1590/0104-530X0893-15

Laurindo, F. J., Shimizu, T., Carvalho, M. M., \& Rabechini, Jr. R. (2001). O papel da tecnologia da informação (TI) na $\begin{array}{lllll}\text { estratégia das } \quad \text { organizações. } & \text { Gestão } e \text { Produção, } & 8(2), & 160-179 .\end{array}$ https://doi.org/10.1590/S0104-530X2001000200005

Lunardi, G. L., Dolci, P. C., \& Maçada, A. C. G. (2010). Adoção de tecnologia de informação e seu impacto no desempenho organizacional: um estudo realizado com micro e pequenas empresas. $R$. Adm, 45(1), 5-17. Retrieved

from http://www.spell.org.br/documentos/ver/4431/adocao-de-tecnologia-de-informacao-e-seu-impacto-no-desempen ho-organizacional--um-estudo-realizado-com-micro-e-pequenas-empresas/i/pt-br

Maciel, A. S., \& Fernandes, R. M. C. (2011). Tecnologias sociais: interface com as políticas públicas e o Serviço Social. Serviço Social \& Sociedade, 105, 146-165. https://doi.org/10.1590/S0101-66282011000100009

Miranda, A. A., Dettmer, C. A., Medeiros, F. F., \& Dettmer, T. L. (2017). Inclusão Digital: o acesso à tecnologia da informação e comunicação pelas famílias rurais do assentamento Juncal, município de Naviraí, MS. Conference Proceedings of the 1st International Meeting on Management, Development and Innovation, Navirai, MS, Brazil. Retrieved from https://periodicos.ufms.br/index.php/EIGEDIN/issue/view/328

Santos, P. V. S. (2019). A introdução de tecnologias a favor da eficiência em operações logísticas: um estudo de caso no setor de serviços. Navus, 9(3), 55-69. https://doi.org/10.22279/navus.2019.v9n3.p55-68.819

Schiavini, J. M., \& Garrido, I. (2018). Análise de Conteúdo, Discurso ou Conversa? Similaridades e Diferenças entre os Métodos de Análise Qualitativa. Revista Adm. Made, 22(2), 1-12. https://doi.org/10.21714/2237-51392018v22n2p001012

Severo, E. A., Guimarães, J. C. F., Gomes, L. H. N. F., Amaral, F. R. C. B., Nascimento, T. A. T., \& Andrade, T. B. F. (2019). A Influência da Orientação Empreendedora e a Gestão do Conhecimento na Performance Organizacional da Indústria de Metalmecânica do Sul do Brasil. Revista de Administração da Unimep, 17(3), 117-140. Retrieved from

http://www.spell.org.br/documentos/ver/55419/a-influencia-da-orientacao-empreendedora-e-a-gestao-do-conhe cimento-na-performance-organizacional-da-industria-de-metalmecanica-do-sul-do-brasil/i/pt-br

Silva, W. A., \& Teixeira, R. M. (2014). Adoção de Tecnologia da Informação pelas Micro e Pequenas Empresas do Setor Hoteleiro de Sergipe. Revista Brasileira de Pesquisa em Turismo, 8(1), 59-77. https://doi.org/10.7784/rbtur.v8i1.605

Siqueira, M. M. (1985). Conflitos no ciclo de vida de um projeto: a desativação de um hospital de hanseníase. Revista de Administração de Empresas, 25(4), 49-53. https://doi.org/10.1590/S0034-75901985000400005

Soares, F. C., \& Beirão Junior, H. F. (2011). Design and management of public projects (2nd ed.). Florianópolis: Publications of IF-SC. 
Vargas, R. V. (2016). Gerenciamento de projetos: estabelecendo diferenciais competitivos (8th ed.). Rio de Janeiro: Brasport.

Yafushi, C. A. P., Almeida, M. F. I., \& Vitoriano, M. C. C. P. (2019). Gestão da Informação, Gestão do Conhecimento, Cultura Organizacional e Competência em Informação: O Quarteto Estratégico para a Construção e Uso Competente da Memória Organizacional. Perspectivas em Gestão \& Conhecimento, 9(3), 4-20. https://doi.org/10.21714/2236-417X2019v9n3p4

\section{Copyrights}

Copyright for this article is retained by the author(s), with first publication rights granted to the journal.

This is an open-access article distributed under the terms and conditions of the Creative Commons Attribution license (http://creativecommons.org/licenses/by/4.0/). 